\title{
PRODUKSI HIDROGEN DARI CAMPURAN AIR DAN MINYAK KELAPA MURNI (VCO) MELALUI POROUS MEDIA TEMBAGA MENGGUNAKAN PRINSIP HYDROGEN REFORMER
}

\author{
Bernardus Crisanto P.M., I.N.G. Wardana, Eko Siswanto \\ Program Magister Teknik Mesin Fakultas Teknik Universitas Brawijaya \\ JL. Mayjend Haryono No.167, Malang 65145, Jawa Timur-Indonesia \\ Email: chris bernardo666@yahoo.com
}

\begin{abstract}
Hydrogen reformer is a principle of hydrogen formation by using the reaction between reactants with a catalyst and a heating process in vapor form. Copper powder was used as the catalyst with a porosity of $28.245 \%$ and $31.736 \%$, and a heat temperature of $310^{\circ} \mathrm{C}$. Variation of the ratio between water and virgin coconut oil (VCO) mixture of 1:1, 1:2, 1:3, 1:4 and 1:5 was developed to investigate the hydrogen generated productivity. The images of burning flame was taken at the outlet pipe of steam reaction to indicate the productivity of the hydrogen. The results shown that the productivity of the hydrogen was obtained by calculating the images of flame colors. The images indicate that the productivity of the hydrogen increase with adding virgin coconut oil (VCO) to water is greater. The average amount of energy and the power needed to react all variations on a comparison of hydrogen reformer tube 5 are $53.53885 \mathrm{~kJ}$ and 0.18666 $\mathrm{kJ} / \mathrm{sec}$, respectively.
\end{abstract}

Keywords: Virgin Coconut Oil (VCO), Hydrogen Reformer, Catalyst Porosity

\section{PENDAHULUAN \\ Latar Belakang}

Indonesia merupakan negara yang kaya akan sumber daya alam, baik sumber daya alam yang bisa diperbarui maupun yang tidak dapat diperbarui. Namun dalam kenyataannya semenjak tahun 2008 pemerintah memenuhi $60 \%$ kebutuhan BBM nasional, dengan cara mengimpor akibat tingginya konsumsi yang tidak diimbangi dengan produksi yang ada. Bahkan impor kebutuhan BBM bisa mencapai $80 \%$ pada 10 tahun lagi, jika tidak ada perbaikan yang dilakukan. Cadangan minyak bumi Indonesia tahun 2014 sebesar 7.549,81 mmstb, dan diperkirakan akan habis beberapa belas tahun lagi dengan asumsi produksi masih tetap seperti saat ini. [5].Oleh karena itu perlunya peningkatan produksi serta energi alternatif dari bahan bakar nabati sebagai pendukung pasokan kebutuhan BBM nasional.

Kelapa merupakan salah satu bahan baku bahan bakar nabati seperti biodiesel dan bioavtur yang saat ini banyak dikembangkan, dimana lahan kelapa di Indonesia sekitar 31,2\% luas area kelapa dunia dengan produksi minyak kelapa 3,2 juta ton/tahun [3]. Produk minyak kelapa yang dihasilkan, kemudian di proses dengan teknologi steam reforming atau hydrogen reformer untuk menghasilkan hidrogen dengan menggunakan panas dan katalis agar ikatan atom dalam molekul terpecah dan bermuatan [4]. Dalam penelitian ini metode hydrogen reformer digunakan untuk memecah bahan baku campuran minyak kelapa dan air, dengan menggunakan katalis dari serbuk tembaga murni $(\mathrm{Cu})$.

\section{Rumusan Masalah}

Atas dasar identifikasi masalah di atas, pada penelitian ini mengambil beberapa permasalahan yang harus diselesaikan yaitu:

1. Bagaimana pengaruh perbandingan campuran air dan minyak kelapa murni (VCO) terhadap produktivitas hidrogen?

2. Berapakah besar energi kalor yang dibutuhkan untuk reaksi pencampuran air dan minyak kelapa murni?

\section{TINJAUAN PUSTAKA \\ Porositas}

Porositas merupakan ruang kosong dari susunan suatu material berbentuk serbuk dalam suatu volume ruang, serta memiliki ketergantungan diantaranya terhadap massa jenis bahan, ukuran bahan, susunan, maupun penyebaran pori [7]. Dalam penelitian ini 
porositas katalis yang digunakan adalah dua ukuran serbuk tembaga yaitu:

a. Serbuk Tembaga dengan ukuran $150 \mu \mathrm{m}$

Berat serbuk $=8,9$ gram, diameter tabung $1,5 \mathrm{~cm}$, tinggi serbuk $=2 \mathrm{~cm}$.

$$
\begin{aligned}
\phi & =1-\frac{8,9 \mathrm{~g}}{\left(8,92 \frac{\mathrm{g}}{\mathrm{cm}^{3}} \cdot 1,76625 \mathrm{~cm}^{2} \cdot 2 \mathrm{~cm}\right)} \times 100 \% \\
& =28,245 \%
\end{aligned}
$$

b. Serbuk Tembaga dengan ukuran $600 \mu \mathrm{m}$

Berat serbuk $=12,5$ gram, diameter tabung $1,5 \mathrm{~cm}$, tinggi serbuk $=2,5 \mathrm{~cm}$.

$$
\begin{aligned}
\phi & =1-\frac{12,5 \mathrm{~g}}{\left(8,92 \frac{\mathrm{g}}{\mathrm{cm}^{3}} \cdot 1,76625 \mathrm{~cm}^{2} \cdot 2,5 \mathrm{~cm}\right)} \times 100 \% \\
& =31,736 \%
\end{aligned}
$$

\section{Reaksi Pencampuran}

Reaksi pemanasan minyak nabati yang mengandung unsur hidrokarbon dan oksigen dengan rumus kimia $\mathrm{C}_{n} \mathrm{H}_{\mathrm{m}} \mathrm{O}_{\mathrm{k}}$, dan dilewatkan katalis, dapat dijabarkan sebagai berikut [2]:

$$
C_{n} H_{m} O_{k}+(2 n-k) H_{2} O \stackrel{\text { Katalis }}{\longrightarrow} n C_{2}+\left(2 n+\frac{m}{2}-k\right) H_{2}
$$

Perbandingan air dan minyak kelapa murni dapat didekati dengan menggunakan kandungan terbesar asam lemak dari minyak kelapa murni yaitu Asam Laurat $\left(\mathrm{C}_{11} \mathrm{H}_{23} \mathrm{COOH}\right)$. Perhitungan perbandingan pencampuran minyak kelapa (VCO) dengan air menggunakan asam laurat $\left[\mathrm{C}_{11} \mathrm{H}_{23} \mathrm{COOH}\right]$ adalah:

$$
\begin{aligned}
& \mathrm{C}_{n} \mathrm{H}_{m} \mathrm{O}_{k}+(2 n-k) \mathrm{H}_{2} \mathrm{O} \stackrel{\text { Katalis }}{\longrightarrow} \mathrm{COO}_{2}+\left(2 n+\frac{m}{2}-k\right) \mathrm{H}_{2} \\
& \stackrel{\mathrm{C}_{12} \mathrm{H}_{24} \mathrm{O}_{2}+(2.12-2) \mathrm{H}_{2} \mathrm{O}}{\text { Katalis }} 12 \mathrm{CO}_{2}+\left(2.12+\frac{24}{2}-2\right) \mathrm{H}_{2} \\
& \mathrm{C}_{12} \mathrm{H}_{24} \mathrm{O}_{2}+22 \mathrm{H}_{2} \mathrm{O} \stackrel{\text { Katalis }}{\longrightarrow} 12 \mathrm{CO}_{2}+34 \mathrm{H}_{2}
\end{aligned}
$$

Dari hasil persamaan reaksi di atas didapatkan perbandingan jumlah mol minyak kelapa murni dengan air adalah 1:22, sehingga perbandingan massa molekul relatif (Mr) keduanya adalah 200: 396. Jika densitas dari minyak kelapa $0,928 \mathrm{~g} / \mathrm{cm}^{3}$ dan densitas air 1 $\mathrm{g} / \mathrm{cm}^{3}$, maka perbandingan volume minyak kelapa dengan air adalah 215,5 : 396 atau bisa disederhanakan menjadi $1: 1,84$.

\section{METODOLOGI PENELITIAN \\ Variabel - Variabel Penelitian}

Dalam penelitian ini variabel yang digunakan dibagi menjadi tiga, yaitu:

- Variabel bebas: perbandingan volume air dengan minyak kelapa murni $1: 1 ; 1: 2 ; 1: 3 ; 1: 4$; dan 1:5 dalam ukuran ml.

- Variabel terikat: luas api hasil pembakaran dan produksi hidrogen (ppm).

- Variabel terkontrol:

1. Temperatur pemanasan katalis $310^{\circ} \mathrm{C}$.

2. Katalis menggunakan serbuk tembaga porositas 28,245 \% dan 31,736\%.

\section{Desain Alat Penelitian}

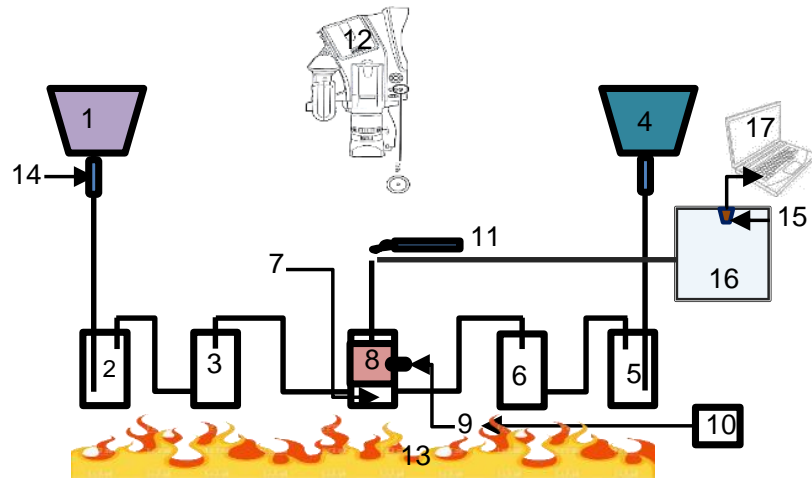

Gambar 1. Skema Alat Uji

Keterangan:

1. Air (aquades)

2. Tabung Pemanas Air

3. Tabung Pemanas Uap Air

4. Minyak Kelapa Murni (VCO)

5. Tabung Pemanas Minyak Kelapa

6. Tabung Pemanas Uap minyak Kelapa

7. Tabung Pencampuran Uap panas lanjut Air dan Minyak Kelapa

8. Katalis porous media tembaga

9. Termokopel tipe-K ukuran $\mathrm{MG}^{*} 1$

10. Temperatur controller TC4S-14R

11. Pemantik Api

12. Kamera Video

13. Kompor Pemanas

14. Infusion set

15. Sensor Hidrogen MQ-8

16. Wadah penampung produksi hidrogen

17. Laptop Axioo neon 
HASIL DAN PEMBAHASAN

Hasil Penelitian

\section{Perhitungan Energi Dan Daya Yang} Dibutuhkan Untuk Reaksi

Perhitungan waktu untuk memanaskan air dan minyak kelapa (VCO) menjadi uap pada masing-masing tabung, dapat dilihat pada tabel di bawah ini:

Tabel 1. Temperatur masing-masing tabung

\begin{tabular}{|c|c|c|c|c|c|c|c|c|}
\hline \multicolumn{3}{|c|}{$\begin{array}{c}\text { Tabung No. } 2 \\
\text { AIR }\end{array}$} & \multicolumn{3}{|c|}{$\begin{array}{c}\text { Tabung No. } 3 \\
\text { AIR }\end{array}$} & \multicolumn{3}{|c|}{$\begin{array}{c}\text { Tabung No. } 5 \\
\text { MINYAK KELAPA }\end{array}$} \\
\hline T1 & T2 & $t$ (detik) & T1 & T2 & $t($ detik$)$ & $\mathbf{T 1}$ & T2 & $t$ (detik) \\
\hline 28 & 100 & 181 & 28 & 99 & 178 & 28 & 178 & \\
\hline 29 & 99.5 & 183 & 28 & 100 & 185 & 28 & 177 & 295 \\
\hline 28 & 100 & 179 & 29 & 100 & 182 & 28 & 176 & 286 \\
\hline 28 & 99 & 183 & 28 & 100 & 186 & 28 & 179 & 290 \\
\hline 28 & 100 & 178 & 28 & 100 & 177 & 29 & 179 & 301 \\
\hline 28.2 & 99.7 & 180.8 & 28.2 & 99.8 & 181.6 & 28.2 & 177.8 & 291.4 \\
\hline
\end{tabular}

\begin{tabular}{cccccc}
\hline \multicolumn{3}{c}{ Tabung No. 6 } & \multicolumn{3}{c}{ Tabung No. 7 } \\
\multicolumn{2}{c}{ MINYAK KELAPA } & \multicolumn{3}{c}{ CAMPURAN } \\
T1 & T2 & t(detik) & T1 & T2 & t(detik) \\
\hline 27.5 & 178 & 297 & 29 & 178 & 383 \\
28 & 177 & 293 & 28 & 177 & 378 \\
28 & 177 & 294 & 28 & 178 & 382 \\
29 & 179 & 290 & 28 & 177 & 380 \\
28 & 178 & 295 & 29 & 177 & 381 \\
$\mathbf{2 8 . 1}$ & $\mathbf{1 7 7 . 8}$ & $\mathbf{2 9 3 . 8}$ & $\mathbf{2 8 . 4}$ & $\mathbf{1 7 7 . 4}$ & $\mathbf{3 8 0 . 8}$ \\
\hline
\end{tabular}

Nilai berat jenis $(\rho)$, berat ( $\mathrm{gr})$, dan specific heat (c) dari air, VCO, serta tabung besi yaitu:
Berat jenis air
$=1 \mathrm{gr} / \mathrm{ml}$
$\rightarrow 0,15 \mathrm{ml}$ air
$=0,15 \mathrm{gr}$
Berat jenis VCO
$=0,916 \mathrm{gr} / \mathrm{ml}$
$\rightarrow 0,15 \mathrm{ml}$ VCO

$$
=0,1374 \mathrm{gr}
$$

Berat tabung No. 2,3,5,6 =176,2 gr

Berat tabung No. $7=266 \mathrm{gr}$

Specific heat air $\quad=4,22 \mathrm{~kJ} / \mathrm{kg} \cdot \mathrm{K}$

Specific heat VCO $\quad=2,10 \mathrm{~kJ} / \mathrm{kg} \cdot \mathrm{K}$

Specific heat besi $\quad=0,45 \mathrm{~kJ} / \mathrm{kg} . \mathrm{K}$

Specific heat campuran air dan VCO yang terjadi pada tabung no.7 sebesar:

$$
\begin{aligned}
& c=\frac{m_{1} c_{1} \Delta T+m_{2} c_{2} \Delta T}{\left(m_{1}+m_{2}\right) \Delta T}= \\
& \frac{\left(0,15 \mathrm{gr} \cdot 4,22 \frac{\mathrm{kJ}}{\mathrm{kg} \cdot \mathrm{K}} \cdot 177,4{ }^{\circ} \mathrm{C}\right)+\left(0,1347 \mathrm{gr} \cdot 2,1 \frac{\mathrm{kJ}}{\mathrm{kg} \cdot \mathrm{K}} \cdot 177,4{ }^{\circ} \mathrm{C}\right)}{(0,15 \mathrm{gr}+0,1347 \mathrm{gr}) 177,4^{\circ} \mathrm{C}} \\
& =3.30188976 \mathrm{~kJ} / \mathrm{kg} \cdot \mathrm{K}
\end{aligned}
$$

Menggunakan persamaan $\mathrm{Q}=$ m.c. $\Delta \mathrm{T}$, maka didapatkan Energi kalor serta daya yang dibutuhkan pada masing masing tabung [1].

Tabel 2. Total kalor dan daya masing-masing tabung pada perbandingan 1:1

\begin{tabular}{ccc}
\hline Tabung & $\begin{array}{c}\text { Total kalor } \\
(\mathrm{kJ})\end{array}$ & $\begin{array}{c}\text { Daya } \\
(\mathrm{kJ} / \text { detik })\end{array}$ \\
\hline No.2 & 5.7144945 & 0.031606717 \\
No.3 & 5.7224868 & 0.031511491 \\
No.5 & 11.90410135 & 0.040851412 \\
No.6 & 11.91205864 & 0.040544788 \\
No.7 & 17.97536715 & 0.04720422 \\
\hline
\end{tabular}

Dengan menggunakan data rekapitulasi tabel di atas dapat disimpulkan bahwa, energi kalor yang dibutuhkan untuk mereaksikan air dengan minyak kelapa (VCO) pada perbandingan 1:1 adalah sebesar $53,23 \mathrm{~kJ}$ dan daya sebesar $0,192 \mathrm{~kJ} /$ detik.

\section{Perhitungan Laju Produksi Hidrogen}

Perhitungan laju produksi dilakukan untuk mengetahui peningkatan produksi hidrogen yang terditeksi melalui sensor hidrogen MQ-8, dimana perhitungannya menggunakan perhitungan regresi pada peningkatan produksi hidrogen per detiknya. [6]

$\mathrm{b}=\frac{\left(n \cdot\left(\Sigma X_{1} Y\right)\right)-\left(\Sigma X_{1}\right)(\Sigma Y)}{\left(n \cdot \Sigma X_{1}^{2}\right)-\left(\Sigma X_{1}\right)^{2}}$

Contoh perhitungan laju produksi hidrogen pada katalis porositas $28,246 \%$ dengan variasi perbandingan air dan minyak kelapa murni 1:1, didapatkan:

$$
\begin{aligned}
\mathrm{b} & =\frac{(565 .(493654221))-(1498879)(159895)}{(565.4328718221)-(1498879)^{2}} \\
& =0,197156
\end{aligned}
$$

\section{Pembahasan}

Pembahasan dilakukan untuk menganalisa pengaruh variasi campuran air dan minyak kelapa murni VCO dengan perbedaan porositas katalis melalui perhitungan luas warna api, produktivitas maupun laju produksi hidrogen.

\section{Analisa Luas Warna Api Variasi Perbandingan Air dan VCO Pada Porositas Katalis 28,245\%.}

Gambar 2 menunjukkan bahwa rata-rata luas warna biru semakin lama semakin 
meningkat dengan persentase luas tertinggi adalah $61,42 \%$ sebesar 234,96 $\mathrm{mm}^{2}$, sedangkan rata-rata luas warna kuning semakin lama semakin menurun dengan persentase luas terendah adalah 38,08\% sebesar $148,18 \mathrm{~mm}^{2}$. Untuk rata-rata luas warna transparan mengGambarkan menunjukkan progres penurunan hingga perbandingan 1:5 dengan persentase terendah adalah $0,5 \%$ sebesar $1,58 \mathrm{~mm}^{2}$. Hal ini dipengaruhi oleh faktor porositas, dimana dengan porositas yang semakin kecil maka luas permukaan untuk berlangsungnya reaksi adalah semakin besar. Dengan penambahan reaktan akan menyebabkan seringnya terjadi tumbukan antar molekul, sehingga produk stoikiometri yang dihasilkan akan menjadi lebih banyak.

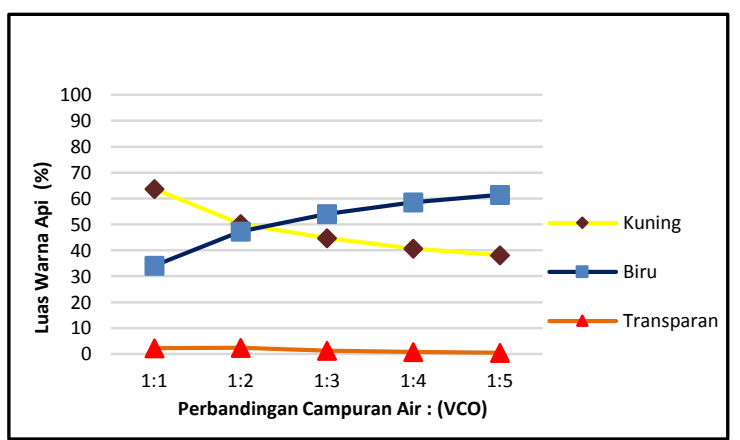

Gambar 2. Rata-rata luas warna api perbandingan campuran air dan VCO pada porositas katalis $28,245 \%$.

\section{Analisa Luas Warna Api Variasi Perbandingan Air dan Minyak Kelapa Murni VCO Pada Porositas Katalis 31,736 \%.}

Gambar 3 menunjukkan hasil yang hampir sama dengan rata-rata luas warna pada porositas katalis $28,246 \%$, dimana rata-rata luas warna biru semakin lama semakin meningkat dengan persentase luas tertinggi adalah $60,14 \%$ sebesar $135,5 \mathrm{~mm}^{2}$, sedangkan rata-rata luas warna kuning semakin lama semakin menurun dengan persentase luas terendah adalah 38,50\% sebesar $93,88 \mathrm{~mm}^{2}$. Untuk rata-rata luas warna transparan mengGambarkan kondisi peningakatan hingga perbandingan 1:5 dengan persentase $1,365 \%$ sebesar 2,6 $\mathrm{mm}^{2}$. Hal ini juga disebabkan karena adanya pengaruh porositas katalis dan penambahan jumlah perbandingan reaktan, sehingga mengakibatkan seringnya kesempatan terjadinya tumbukan antar molekul yang menyebabkan produk stoikiometrinya yaitu api warna biru meningkat.

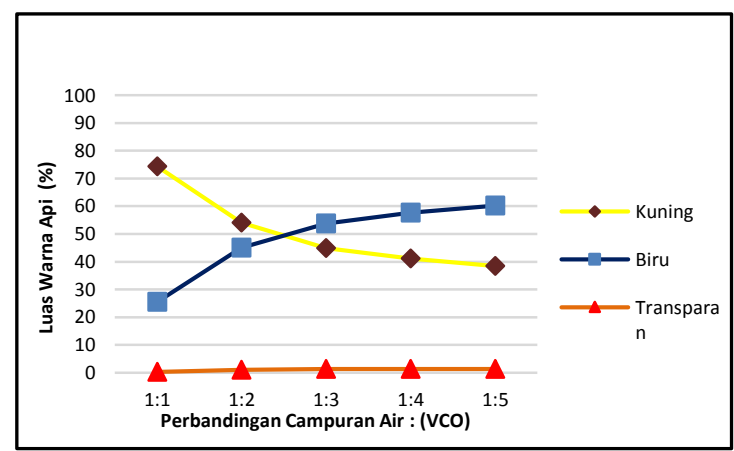

Gambar 3. Rata-rata luas warna api perbandingan campuran air dan VCO pada porositas katalis $31,736 \%$.

\section{Analisa Rata-rata Luas Warna Api Pada Kedua Porositas Katalis.}

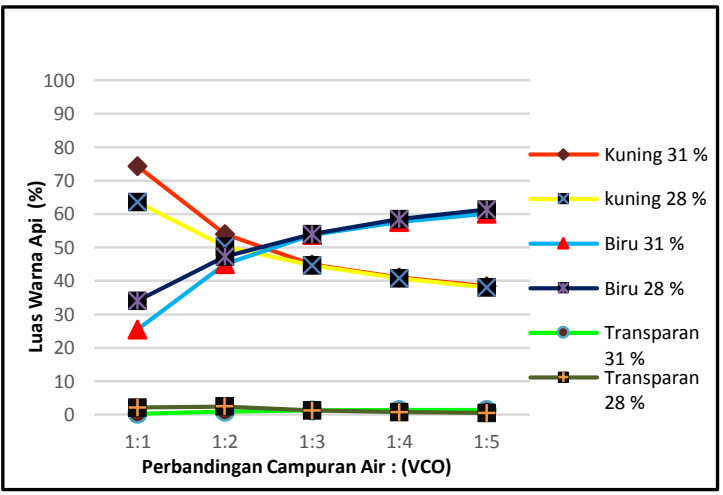

Gambar 4. Rata-rata luas warna api perbandingan campuran air dan VCO pada kedua porositas katalis.

Gambar 4 menunjukkan kemiripan ratarata luas warna pada porositas katalis $28,245 \%$ dan $31,736 \%$, dimana rata-rata luas warna biru cenderung mengalami peningkatan sedangkan rata-rata luas warna kuning cenderung mengalami penurunan. Jika dilihat dari nilai persentase masing-masing luas warna biru pada setiap perbandingan, terlihat bahwa ratarata luas warna biru pada porositas katalis $28,245 \%$ lebih besar daripada rata-rata luas warna pada porositas katalis $31,736 \%$. Hal ini menunjukkan bahwa pada porositas katalis $28,245 \%$ produktivitas stoikiometri yang dihasilkan adalah lebih besar, karena jika dilihat 
dari nilai luas sebenarnya $\left(\mathrm{mm}^{2}\right)$ terlihat bahwa nilai rata-rata luas dari masing-masing perbandingan pada porositas katalis $28,245 \%$ jauh lebih besar. Sehingga dengan porositas yang semakin kecil, maka besar luas warna $\left(\mathrm{mm}^{2}\right)$ yang dihasilkan akan semakin besar. Menimbang hasil analisa di atas maka dapat disimpulkan bahwa luas warna biru dapat dijadikan sebagai Gambaran hasil produktivitas hidrogen, dimana dengan dengan penambahan konsentrasi minyak kelapa murni (VCO) lebih besar daripada air akan meningkatkan produktivitas hidrogen yang dihasilkan.

Analisa Produksi Hidrogen Dari Variasi Perbandingan Air dan VCO Pada Porositas Katalis 28,245 \% Menggunakan Sensor Hidrogen MQ-8.

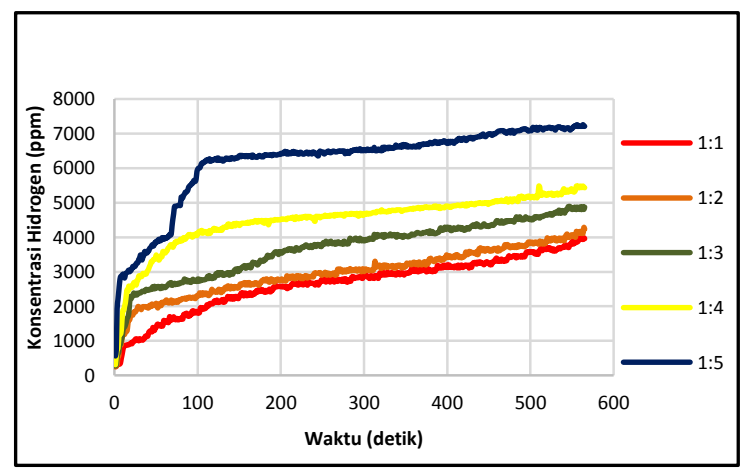

Gambar 5. Produksi hidrogen dari variasi perbandingan campuran air dan VCO pada porositas katalis $28,245 \%$.

Gambar 5 menunjukkan bahwa semakin besar penambahan minyak kelapa murni (VCO) pada variasi perbandingan terhadap air, maka hidrogen yang di produksi juga semakin meningkat. Dimana produktivitas hidrogen tertinggi pada perbandingan $1: 1$ adalah 3988 ppm, perbandingan 1:2 adalah $4287 \mathrm{ppm}$, perbandingan 1:3 adalah $4896 \mathrm{ppm}$, perbandingan 1:4 adalah $5476 \mathrm{ppm}$, dan perbandingan $1: 5$ adalah $7255 \mathrm{ppm}$. Hal ini disebabkan karena banyaknya kandungan atom hidrogen pada minyak kelapa, yang mendapatkan kesempatan untuk saling bertumbukan dan bereaksi dengan molekul air pada permukaan katalis.

\section{Analisa Produksi Hidrogen Dari Variasi Perbandingan Air dan VCO Pada Porositas Katalis 31,736\% Menggunakan Sensor Hidrogen MQ-8.}

Gambar 6 menunjukkan peningkatan produksi hidrogen pada masing-masing perbandingan, seperti pada porositas katalis $28,245 \%$. Dimana produktivitas hidrogen tertinggi pada perbandingan 1:1 adalah 3494 ppm, perbandingan 1:2 adalah $3582 \mathrm{ppm}$, perbandingan 1:3 adalah $3698 \mathrm{ppm}$, perbandingan 1:4 adalah 3862 ppm, dan perbandingan 1:5 adalah $4896 \mathrm{ppm}$. Hal ini terlihat bahwa dengan semakin banyaknya kandungan atom hidrogen pada minyak kelapa yang saling bertumbukan dan bereaksi dengan molekul air pada permukaan katalis, menyebabkan produktivitas hidrogen semakin meningkat.

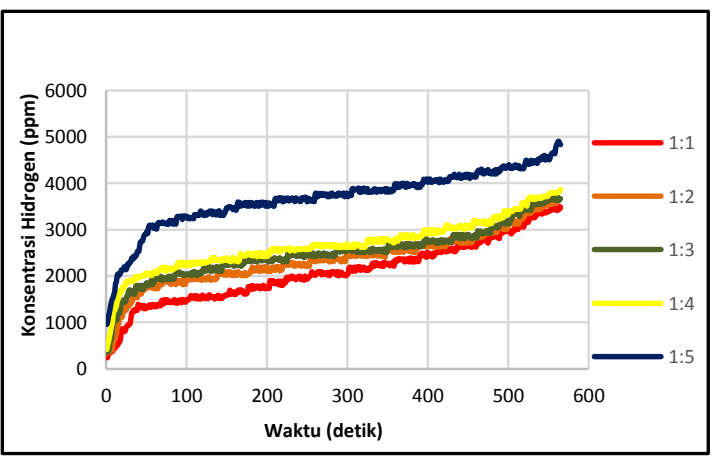

Gambar 6. Produksi hidrogen dari variasi perbandingan campuran air dan VCO pada porositas katalis $31,736 \%$.

\section{Analisa Rata-rata Produksi Hidrogen Pada Kedua Porositas Katalis.}

Gambar 7 menunjukkan bahwa rata-rata produktivitas hidrogen yang terdeteksi oleh sensor hidrogen MQ-8, berbanding lurus dengan peningkatan variasi perbandingan campuran. Selain itu pada porositas katalis $28,245 \%$ menghasilkan produktivitas hidrogen yang lebih besar, dari pada porositas katalis $31,736 \%$. Rata-rata produktivitas hidrogen pada perbandingan 1:5 dengan porositas katalis 28,245\% adalah sebesar 6186 ppm, sedangkan pada porositas $31,736 \%$ adalah sebesar 3669 ppm. Hal ini disebabkan karena dengan porositas katalis yang semakin kecil maka akan memiliki luas permukaan reaksi yang semakin besar, serta dengan banyaknya penambahan reaktan akan meningkatkan 
kerapatan antar partikel sehingga tumbukan perbandingan 1:4 adalah 0,30618 ppm/dt, dan antar molekul pada permukaan katalis akan sering terjadi.

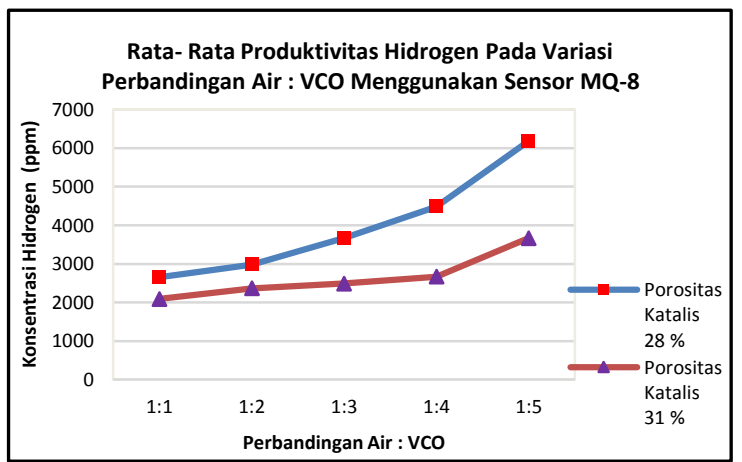

Gambar 7. Rata-rata produksi hidrogen dari variasi perbandingan campuran air dan VCO menggunakan sensor MQ-8.

Analisa Laju Produksi Hidrogen Dari Variasi Perbandingan Air dan (VCO) Pada Porositas Katalis 28,245 \% Menggunakan Sensor Hidrogen MQ-8.

Gambar 8 menunjukkan bahwa rata-rata laju produksi hidrogen berbanding lurus dengan rata-rata produkivitas hidrogen yang dihasilkan pada setiap perbandingan, dimana semakin besar penambahan minyak kelapa murni (VCO) pada variasi perbandingan terhadap air serta waktu pemanasan, maka laju produksi hidrogen yang dihasilkan juga semakin meningkat.

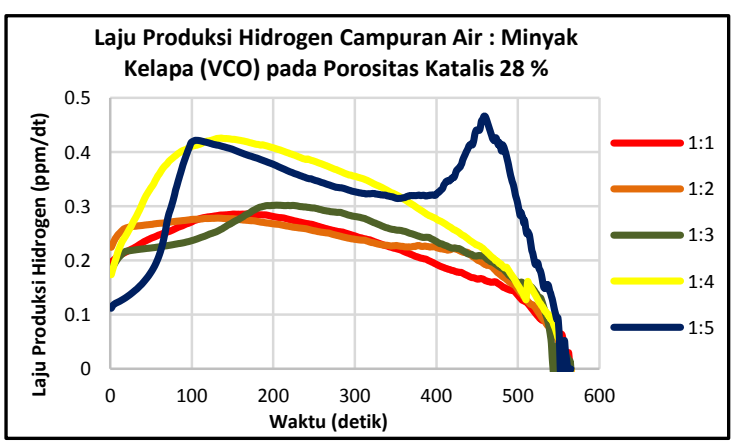

Gambar 8. Laju produksi hidrogen dari variasi perbandingan campuran air dan VCO pada porositas katalis $28,245 \%$.

Dimana rata-rata laju produksi hidrogen pada perbandingan 1:1 adalah 0,21824 ppm/dt, perbandingan 1:2 adalah 0,22633 ppm/dt, perbandingan $1: 3$ adalah $0,23178 \mathrm{ppm} / \mathrm{dt}$, perbandingan 1:5 adalah $0,31566 \mathrm{ppm} / \mathrm{dt}$. Hal ini disebabkan karena semakin meningkatnya jumlah reaktan dan luas permukaan, maka kesempatan molekul reaktan untuk saling bertumbukan akan lebih sering terjadi, sehingga laju produksi hidrogen juga akan semakin cepat.

Analisa Laju Produksi Hidrogen Dari Variasi Perbandingan Air dan (VCO) Pada Porositas Katalis 31,736 \% Menggunakan Sensor Hidrogen MQ-8.

Gambar 9 menunjukkan bahwa rata-rata laju produksi hidrogen mengalami peningkatan pada setiap variasi perbandingan terhadap waktu pemanasan. Rata-rata produktivitas hidrogen pada perbandingan 1:1 adalah $0,185024 \mathrm{ppm} / \mathrm{dt}$, perbandingan 1:2 adalah $0,208703 \mathrm{ppm} / \mathrm{dt}$, perbandingan $1: 3$ adalah $0,210564 \mathrm{ppm} / \mathrm{dt}$, perbandingan $1: 4$ adalah $0,222223 \mathrm{ppm} / \mathrm{dt}$, dan perbandingan 1:5 adalah $0,258884 \mathrm{ppm} / \mathrm{dt}$. Hal ini sesuai dengan semakin meningkatnya jumlah reaktan dan lama waktu pemanasan, maka masing-masing molekul reaktan akan saling bertumbukan akibat peningkatan jumlah partikelnya serta lebih rapat, sehingga laju produksi hidrogen juga akan semakin cepat.

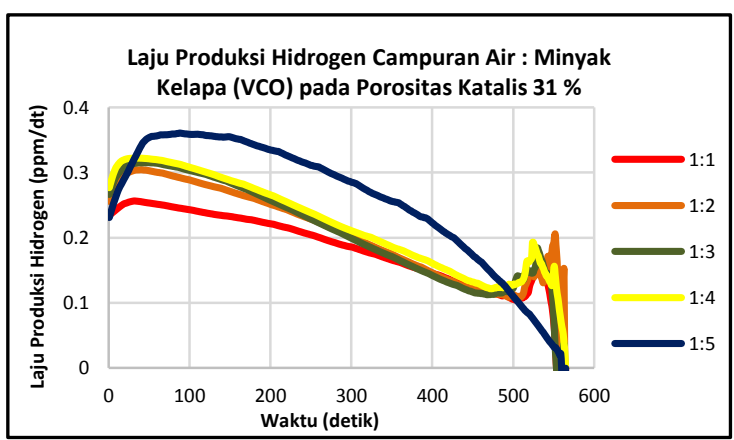

Gambar 9. Laju produksi hidrogen dari variasi perbandingan campuran air dan VCO pada porositas katalis $31,736 \%$

Analisa Rata-rata Laju Produksi Hidrogen Dari Variasi Perbandingan Air dan Minyak Kelapa Murni (VCO) Pada Porositas Katalis 28,245 \% dan 31,736\% Menggunakan Sensor $M Q-8$.

Gambar 10 menunjukkan bahwa rata-rata laju produktivitas hidrogen yang terdeteksi oleh sensor hidrogen MQ-8, berbanding lurus 
dengan peningkatan variasi perbandingan lebih besar dari pada porositas katalis 31,736 campuran. Selain itu faktor porositas katalis \%. sangat berpengaruh terhadap kecepatan produksi, dimana laju produksi hidrogen pada porositas katalis $28,245 \%$ lebih besar dari pada porositas katalis $31,736 \%$. Hal ini disebabkan karena dengan porositas katalis yang semakin kecil, maka akan memiliki luas permukaan reaksi yang semakin besar. Dengan semakin besar luas permukaan tersebut maka molekul reaktan akan memiliki banyak tempat untuk saling bertumbukan, sehingga berdampak langsung pada peningkatan laju produksi.

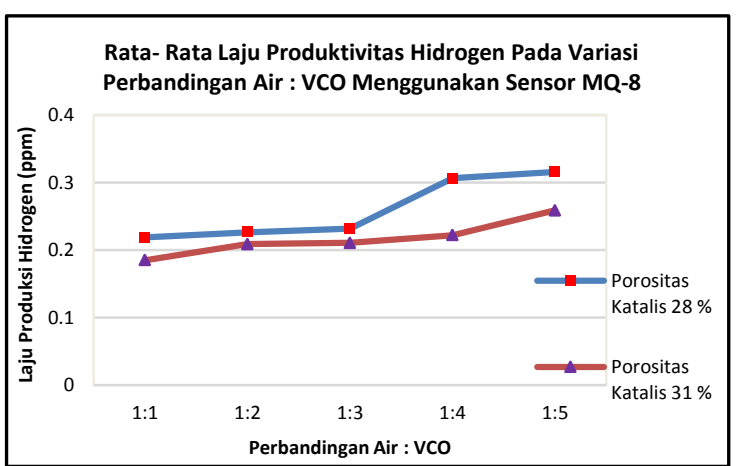

Gambar 10. Rata-rata laju produksi hidrogen dari variasi perbandingan campuran air dan VCO menggunakan sensor MQ-8.

\section{KESIMPULAN}

Dari analisa pembahasan pengaruh ukuran porositas katalis terhadap produksi hidrogen dengan perbandingan variasi campuran air dan minyak kelapa murni (VCO), dapat diambil beberapa kesimpulan sebagai berikut:

Penggunaaan tembaga sebagai katalis ternyata dapat mereaksikan minyak kelapa dengan air untuk menghasilkan hidrogen, dimana tembaga dijadikan katalis dalam bentuk serbuk agar memiliki pori atau porositas sebagai tempat berlangsungnya reaksi. Pengaruh penambahan campuran jumlah massa reaktan juga sangat mempengaruhi, dimana dengan penanambahan jumlah massa minyak kelapa murni (VCO) terhadap air akan meningkatkan produktivitas hidrogen. Hal ini berkesinambungan dari hasil analisa luas api warna biru $\left(\mathrm{mm}^{2}\right)$, produksi hidrogen dan laju produksi hidrogen, dimana terlihat bahwa porositas katalis yang semakin kecil yaitu pada porositas $28,245 \%$ menunjukkan hasil yang kalor untuk mereaksikan pencampuran air dan minyak kelapa murni (VCO) dari semua variasi perbandingan yang ditempatkan pada 5 tabung hydrogen reformer adalah 53,538845 kJ, sedangkan kebutuhan rata-rata daya yang diperlukan adalah sebesar 0,18666 kJ/detik

\section{DAFTAR PUSTAKA}

[1] Dali S. Naga, 1991. Fisika Ilmu Panas Edisi Kedua. Penerbit Gunadarma

[2] Ekaterini Ch. Vagia dan Angeliki A. Lemonidou, 2008. Steam Reforming Of Bio-Oil Component (Acetic Acid) For Hydrogen Production-Effect Of Active Metal And Support Materials

[3] Fathurrachman Fagi 2016, kondisi EBT di Indonesia.

http://energibarudanterbarukan.blogspot.c o.id/2011/02/kondisi-ebt-saat-ini-diindonesia.html (diakses tgl 1 maret 2016)

[4] I.N.G. Wardana, 2008. Bahan Bakar dan Teknologi Pembakaran, PT. Danar WijayaBrawijaya University Press, Malang

[5] Kementrian ESDM, 2015. Impor BBM Kok Merasa Kaya Migas. www.esdm.go.id (diakses 1 maret 2016).

[6] Matondang Zulkifli, 2007. Perhitungan Uji Linieritas dan Keberartian Persamaan Regresi.

www.google.co.id/\#q=+Dr. + ZulkifliMatond ang\%2C+M.Si.2007 (diakses 24 Juni 2016)

[7] M. Nasikin, Praswasti P.D.K Wulan, Vita Andrianty, 2004. Permodelan Dan Katalitik Konverter Packed Bed Untuk Mengoksidasi Jelaga Pada Gas Buang Kendaraan Bermesin Diesel. Teknik Kimia Universitas Indonesia. 